\section{Peperomia sandwicensis 'Palikea': A Small, Native Hawaiian Plant for Compact Indoor Spaces}

\author{
Orville C. Baldos \\ Department of Tropical Plant and Soil Sciences, University of Hawaii at \\ Manoa, St. John Plant Science Lab 102, 3190 Maile Way, Honolulu, HI 96822
}

\section{Aleta Corpuz \\ Buildings and Grounds Management, University of Hawaii at Manoa, 2002 East West Road, Honolulu, HI 96822 \\ Lindsey Watanabe \\ Department of Tropical Plant and Soil Sciences, University of Hawaii at Manoa, St. John Plant Science Lab 102, 3190 Maile Way, Honolulu, HI 96822}

Additional index words. desk plant, office plant, singlespike peperomia, source-identified germplasm, tabletop plant

Peperomia, a member of the family Piperaceae, is a large, pantropical genus comprising $\approx 1600$ species worldwide (Frodin, 2004; Lim et al., 2019). Many species and cultivars of Peperomia have been popular as small houseplants since the 1930s (Griffith, 2006).

In Hawaii, the genus Peperomia comprises two indigenous and 23 endemic species (Wagner et al., 1999). These account for nearly one-quarter of the species diversity in the Pacific Islands (Lim et al., 2019). Although several Hawaiian species possess a compact growing habit and have interesting leaf and stem coloration, research of the ornamental potential of these native species has been limited. Currently, Peperomia blanda is the only native Hawaiian species that is commercially sold as an ornamental/landscape plant in the state (Baldos and Corpuz, 2019).

Peperomia sandwicensis Miq. is a small perennial herb that is endemic to the islands of Kauai, Oahu, and Molokai. It typically grows up to $30 \mathrm{~cm}$ tall and is found growing on top of moss-covered rocks, in soil, or as an epiphyte in wet to mesic valleys to wet forests at elevations between 250 and $1220 \mathrm{~m}$ above sea

Received for publication 28 June 2021. Accepted for publication 2 Aug. 2021.

Published online 10 September 2021.

We thank the Harold Lyon Arboretum and the State of Hawaii Department of Land and Natural Resources, Division of Forestry and Wildlife, for granting access to the plant materials for this work. We also thank Sherry Ann Hara for assisting us with data collection. This research was supported in part by the U.S. Department of Agriculture (USDA) National Institute of Food and Agriculture (NIFA) Hatch project HAW08040-H, managed by the College of Tropical Agriculture and Human Resources, University of Hawaii at Manoa, and by the Hawaii Department of Agriculture NEWGERMPLASM17 grant.

O.C.B. is the corresponding author. E-mail: obaldos@hawaii.edu.

This is an open access article distributed under the CC BY-NC-ND license (https://creativecommons. org/licenses/by-nc-nd/4.0/) level (Wagner et al., 1999). Its small size, dark green upper leaf surface, reddish stems, and reddish leaf undersides suggest its potential use as an indoor plant. This germplasm release article describes 'Palikea', an Oahu Island selection of Peperomia sandwicensis.

\section{Origin}

Peperomia sandwicensis 'Palikea' originated from a stem cutting collected from a wild population in West Oahu by botanist Joel Lau in Dec. 2012, and deposited at the Harold Lyon Arboretum in Honolulu. In June 2016, a plant from that collection was brought to the University of Hawaii at Manoa Magoon Research Facility for evaluation. In 2017, a preliminary study under indoor conditions $\left(23.1^{\circ} \mathrm{C}\right.$ and $54.8 \%$ relative humidity) suggested that Peperomia sandwicensis 'Palikea' can survive under office light conditions (daily light integral $\left.[\mathrm{DLI}]=0.4 \mathrm{~mol} \cdot \mathrm{m}^{-2} \cdot \mathrm{d}^{-1}\right)$ or low light levels (DLI $=0.2 \mathrm{~mol} \cdot \mathrm{m}^{-2} \cdot \mathrm{d}^{-1}$ ) for 6 months (Baldos and Corpuz, 2019). In 2020, visual quality assessments under three T8 light-emitting diode (LED) lighting conditions (DLI = $2.9 \mathrm{~mol} \cdot \mathrm{m}^{-2} \cdot \mathrm{d}^{-1}, 0.4 \mathrm{~mol} \cdot \mathrm{m}^{-2} \cdot \mathrm{d}^{-1}$, and 0.2 $\mathrm{mol} \cdot \mathrm{m}^{-2} \cdot \mathrm{d}^{-1}$ ) confirmed Peperomia sandwicensis 'Palikea' as a promising indoor plant selection.

Description. Peperomia sandwicensis 'Palikea' has a compact growth habit that is suitable for small containers (7.6- to $10.2-\mathrm{cm}$ diameter pots) (Fig. 1). Leaves are elliptic, thick, fleshy, 0.7 to $1.7 \mathrm{~cm}$ wide, and 0.9 to 2.4 $\mathrm{cm}$ long. The upper leaf surface is glabrous and dark green (RHS N137A), usually with three light green (RHS 138D) veins radiating outward from the base of the leaf (Royal Horticultural Society, 2007). Aside from the three main veins, smaller, light green secondary veins may also appear on the upper leaf surface. These veins may be slightly impressed on the surface (Wagner et al., 1999). Leaf undersides are pubescent and red-purple (RHS 59A) with light green (RHS 138D) to pinkish
(N170D) venation. Stems are ascending to weakly erect (Wagner et al., 1999), and there is good branching. Stem color ranges from red-purple (RHS 59A) to greyed orange (RHS 166A). The average length of the internodes is $1.3 \mathrm{~cm}$. Floral spikes are solitary and produced terminally or sometimes laterally (Wagner et al., 1999). The spike length can be up to 13 $\mathrm{cm}$. Its slight curvature adds ornamental value. Plants have an average of 3.9 basal shoots at 1 year after propagation from leaf cuttings.

\section{Performance}

Baldos and Corpuz (2019) evaluated the survival of Peperomia sandwicensis 'Palikea' and three other native Hawaiian species ( $P$. blanda, $P$. cookiana, and $P$. oahuensis) for 6 months under a window $\left(2.4 \mathrm{~mol} \cdot \mathrm{m}^{-2} \cdot \mathrm{d}^{-1}\right)$, T12 $\mathrm{fl}$ uorescent office lighting $\left(0.4 \mathrm{~mol} \cdot \mathrm{m}^{-2} \cdot \mathrm{d}^{-1}\right)$, and under low T12 fluorescent lighting $\left(0.2 \mathrm{~mol} \cdot \mathrm{m}^{-2} \cdot \mathrm{d}^{-1}\right)$. Results of this study indicated that Peperomia sandwicensis 'Palikea' had the highest survival rate among the four species in both low light and office light conditions $(P<0.001)$. At 6 months, Peperomia sandwicensis 'Palikea' had $60 \%$ survival with the low light treatment and $100 \%$ survival with the office light treatment. Under window light, it survived better than $P$. cookiana and $P$. oahuensis $(P<0.002)$. Survival curves of Peperomia sandwicensis 'Palikea' and $P$. blanda under window light were not different $(P=0.98)$ (Baldos and Corpuz, 2019).

In 2020, the growth and visual quality of Peperomia sandwicensis 'Palikea' under three T8 replacement LED indoor light conditions (DLI $=2.9 \mathrm{~mol} \cdot \mathrm{m}^{-2} \cdot \mathrm{d}^{-1}, 0.4 \mathrm{~mol} \cdot \mathrm{m}^{-2} \cdot \mathrm{d}^{-1}$, and $0.2 \mathrm{~mol} \cdot \mathrm{m}^{-2} \cdot \mathrm{d}^{-1}$ ) were evaluated. In this study, plants were propagated from leaf or stem cuttings and grown in 5-cm pots filled with a 1:1 (v/v) mix of calcined clay (Turface MVP; PROFILE Products, Buffalo Grove, IL) and fine orchid bark (Orchiata Orchid Bark, Precision Grade; Pacific Bark Limited, Matamata, New Zealand). Slow-release fertilizer ( $13 \mathrm{~N}-4.8 \mathrm{P}-$ 9.1K; Nutricote; Arysta LifeScience America, New York, NY) was incorporated with the growing media at a rate of $7.1 \mathrm{~g} / \mathrm{L}$.

Plants were grown indoors $\left(22.6{ }^{\circ} \mathrm{C}\right.$ and $59.5 \%$ relative humidity) for 7 to 9 months under LED growlights (2-ft Growlight; Feit Electric Company, Pico Rivera, CA) with a daily light integral of $4.3 \mathrm{~mol} \cdot \mathrm{m}^{-2} \cdot \mathrm{d}^{-1}$. Two months before the indoor trial, plants were potted in the final plastic pots $(7.6 \mathrm{~cm}$ in diameter, $8.0 \mathrm{~cm}$ tall). These were filled with the same media and the same rate of slowrelease fertilizer. Plants were hand-watered using a watering can twice every week.

Plants were grown under T8 replacement LED light bulbs (Hyperikon, Indianapolis, IN) for 2 months at a DLI of $8.6 \mathrm{~mol} \cdot \mathrm{m}^{-2} \cdot \mathrm{d}^{-1}$, which was then lowered to a DLI of $4.3 \mathrm{~mol} \cdot \mathrm{m}^{-2} \cdot \mathrm{d}^{-1}$ at 1 week before the experiment. In May 2020, the plants were sorted based on size and placed under three T8 replacement LED lighting conditions $\left[\right.$ DLI $=2.9 \mathrm{~mol} \cdot \mathrm{m}^{-2} \cdot \mathrm{d}^{-1}$ (control), 0.4 $\mathrm{mol} \cdot \mathrm{m}^{-2} \cdot \mathrm{d}^{-1}$ (office light), and $0.2 \mathrm{~mol} \cdot \mathrm{m}^{-2} \cdot \mathrm{d}^{-1}$ (low light)]. Plants were hand-watered once per 


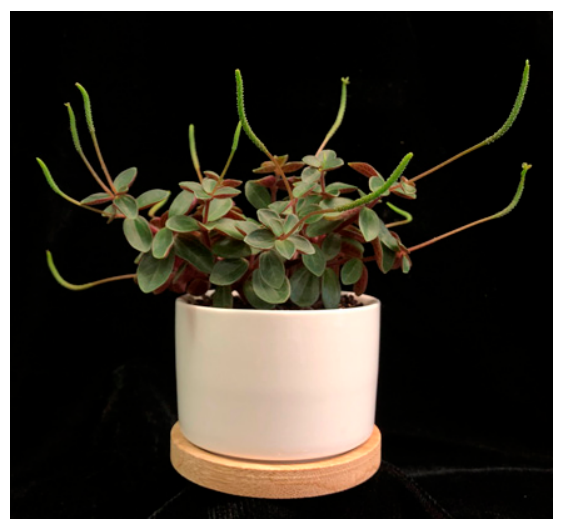

Fig. 1. Peperomia sandwicensis 'Palikea' (grown 10 months indoors after propagation) in an 8$\mathrm{cm}$-diameter ceramic pot with $1: 1 \mathrm{v} / \mathrm{v}$ calcined clay and orchid bark.

week with $30 \mathrm{~mL}$ of tap water. The experiment was performed using a randomized complete block design with six replicates. Plant size was considered a blocking factor. Height and canopy diameter at 0,3 , and 6 months under the three light conditions were recorded. Visual quality ratings [1 = poor; 2 = fair (not saleable); 3 = acceptable (saleable); 4 = good quality; and $5=$ excellent quality] adapted from Henny and Chen (2011) were also recorded at 0,3 , and 6 months. Data from each month were analyzed using analysis of variance procedures in Statistix 10 (Analytical Software, Tallahassee, FL). Because height data collected at 3 months showed significance for nonadditivity, $\log$ transformation was performed before reanalysis. Significant treatment means were separated based on the Tukey's honestly significant difference test at $P<0.05$.

At the beginning of the experiment, no significant differences in height and canopy diameter of plants were observed. At 3 months under

Table 1. Height, canopy diameter, and visual quality of Peperomia sandwicensis 'Palikea' after 0,3 , and 6 months of growth under three light levels and interior conditions $\left(22.6{ }^{\circ} \mathrm{C}\right.$ and $59.5 \%$ relative humidity).

\begin{tabular}{|c|c|c|c|c|c|c|c|c|c|}
\hline \multirow{2}{*}{$\begin{array}{l}\text { Daily light integral } \\
\text { Month }\end{array}$} & \multicolumn{3}{|c|}{$\mathrm{Ht}(\mathrm{cm})$} & \multicolumn{3}{|c|}{ Diam $(\mathrm{cm})$} & \multicolumn{3}{|c|}{ Visual quality $^{z}$} \\
\hline & 0 & $3^{\mathrm{y}, \mathrm{x}}$ & $6^{\mathrm{y}}$ & 0 & $3^{\mathrm{y}}$ & $6^{\mathrm{y}}$ & 0 & 3 & $6^{\mathrm{y}}$ \\
\hline $0.2 \mathrm{~mol} \cdot \mathrm{m}^{-2} \cdot \mathrm{d}^{-1}$ & 6.3 & $6.3 \mathrm{~b}$ & $7.0 \mathrm{~b}$ & 9.5 & $10.8 \mathrm{ab}$ & $10.9 \mathrm{~b}$ & 4.1 & 4.1 & $4.1 \mathrm{ab}$ \\
\hline $0.4 \mathrm{~mol} \cdot \mathrm{m}^{-2} \cdot \mathrm{d}^{-1}$ & 6.8 & $8.0 \mathrm{a}$ & $9.6 \mathrm{a}$ & 7.6 & $10.1 \mathrm{~b}$ & $9.8 \mathrm{~b}$ & 3.9 & 4.1 & $3.8 \mathrm{~b}$ \\
\hline $2.9 \mathrm{~mol} \cdot \mathrm{m}^{-2} \cdot \mathrm{d}^{-1}$ & 7.1 & $7.6 \mathrm{a}$ & $7.0 \mathrm{~b}$ & 8.4 & $12.7 \mathrm{a}$ & $13.9 \mathrm{a}$ & 4.2 & 4.5 & $4.6 \mathrm{a}$ \\
\hline$P$ value & NS & 0.0014 & 0.0134 & NS & 0.0421 & 0.0040 & NS & NS & 0.0355 \\
\hline
\end{tabular}

${ }^{\mathrm{z}}$ Visual quality: 1 = poor; $2=$ fair; $3=$ saleable; $4=$ good; and $5=$ excellent.

${ }^{\mathrm{y}}$ Means followed by a different letter in the same column are significantly different $(P<0.05)$ based on Tukey's honestly significant difference (HSD) test.

${ }^{\mathrm{x}}$ Mean height presented at 3 months are original means. Tukey's HSD test is based on log-transformed means.

NS $=$ not significant

indoor conditions, Peperomia sandwicensis ' $\mathrm{Pa}$ likea' under control and office light was taller than that under low light conditions (Table 1). At 6 months under indoor conditions, plants subjected to the office light treatment were significantly taller than the control and those subjected to low light treatments. The canopy diameter at 3 and 6 months under indoor conditions was greatest for the control plants, whereas plants subjected to office light and low light conditions exhibited similar canopy diameters. Visual quality ratings of light treatments were not significantly different at 0 and 3 months under indoor conditions. At 6 months under indoor conditions, there was a significant, but slight, decrease in the visual quality of plants grown with the office light treatment (Table 1). Regardless of the light treatment, all plants were graded as good quality $(>3.8)$ at 0,3 , and 6 months under interior conditions.

\section{Availability}

Peperomia sandwicensis 'Palikea' is made available to interested nurseries in Hawaii.
Contact Orville Baldos (e-mail: obaldos@ hawaii.edu) for inquiries.

\section{Literature Cited}

Baldos, O.C. and A.K. Corpuz. 2019. Survival of four native Hawaiian Peperomia species under three indoor light conditions. HortScience 54(9):S229 (abstr.).

Frodin, D.G. 2004. History and concepts of big plant genera. Taxon 53(3):753-776, doi: $10.2307 / 4135449$.

Griffith, L.P., Jr. 2006. Tropical foliage plants: A grower's guide. 2nd ed. Ball Publishing, Batavia, IL.

Henny, R.J. and J. Chen. 2011. 'Leprechaun' $A g$ laonema. HortScience 46(6):950-951, doi: 10.21273/HORTSCI.46.6.950.

Lim, J.Y., C.R. Marshall, E.A. Zimmer, and W.L. Wagner. 2019. Multiple colonizations of the Pacific by Peperomia (Piperaceae): Complex patterns of long-distance dispersal and parallel radiations on the Hawaiian Islands. J. Biogeogr. 46(12):2651-2662, doi: 10.1111/jbi.13717.

Royal Horticultural Society. 2007. Royal Horticultural Society colour chart. RHS, London, UK.

Wagner, W., D. Herbst, and S.H. Sohmer. 1999 Manual of the flowering plants of Hawaii, revised ed. Univ. Hawaii Press, Honolulu, HI. 